\title{
"A NOISELESS PATIENT SPIDER": Whitman's Beauty-Blood and Brain
}

\author{
Paul Diehl
}

IN THE PREFACE to Leaves of Grass (1855), Whitman presents the principles that will direct his poetry and the poetry of generations of American poets to come:

The poetic quality is not marshalled in rhyme or uniformity or abstract addresses to things nor in melancholy complaints or good precepts, but is the life of these and much else and is in the soul. The profit of rhyme is that it drops seeds of a sweeter and more luxuriant rhyme, and of uniformity that it conveys itself into its own roots in the ground out of sight. The rhyme and uniformity of perfect poems show the free growth of metrical laws and bud from them as unerringly and loosely as lilacs or roses on a bush, and take shapes as compact as the shapes of chestnuts and oranges and melons and pears, and shed the perfume impalpable to form. The fluency and ornaments of the finest poems or music or orations or recitations are not independent but dependent. All beauty comes from beautiful blood and a beautiful brain. ${ }^{1}$

Such things as rhyme and uniformity (meter, stanza form) are not the cause of poetic quality. Rather, poetic quality is the cause, the "life" of rhyme and uniformity. Rhymes and uniformities may in fact be found in "perfect poems," but the perfection arises from something deeper. Whitman had not dismissed poetic forms - he simply had followed them to their natural consequences. "The profit of rhyme drops seeds of a sweeter and more luxuriant rhyme." Uniformity "conveys itself into its own roots in the ground out of sight." Rhyme leads us to a newer rhyme, suggests the potential that was always there in the germ of the matter; uniformity takes us back to its source, to what was always there at the root of the matter. The poetic forms of "perfect poems" have always suggested the possibilities of the principle that resulted in the forms in the first place. Sometimes in "perfect poems" the principle leads to shapes we know as rhyme and meter and stanza forms, "take shapes as compact as the shapes of chestnuts and oranges and melons and pears," all things which bear the germ of the branching organism, tree or vine, that makes them possible. Sometimes such shapes delineate the natural extension of the principle by showing "the free growth of metrical laws" and budding "from them as unerringly and loosely as lilacs or roses on a bush."2 And sometimes the principle leads to poetry that sheds "the perfume impalpable to form." But whatever the form, open as a tree, closed as a pear, the principle is the same, a process that starts "in the soul," from roots deep in the ground. 
This part of the Preface celebrates organic form, no question, and that has been detailed before and by many others. ${ }^{3}$ What I want to do is examine more closely the poetic principle itself, the Rhyme behind rhyme, the Uniformity behind uniformity. We can make a beginning by noticing the shift in Whitman's metaphors at the end of the passage cited above, in the shift from seeds and roots and the luxuriant growth of plants to other branching potentials: "All beauty comes from beautiful blood and a beautiful brain." Whitman locates beauty, the poetic principle, in the combination of flesh and mind, pulse and thought, sound and idea. Earlier in the Preface Whitman uses a different metaphor but in a similar vein when he calls for a national poet whose "spirit responds to his country's spirit. ... he incarnates its geography and natural life, and rivers and lakes." Here two spirits are in resonance as the poet gives physical form (language) to what is already physical (the country). And this is the heart of Whitman's American poetics - the combination of two forms of the physical connected by resonant spirits. It wasn't new, Whitman knew that (the Preface begins with "America does not repel the past"), but he also knew the time had come to renew the sense of poetry, to shake off the ornaments that had come to be so strongly associated with poetry that they were assumed to be poetry itself, to extend into new light the principle by which poets had always connected sound and sense: analogical thought - the stuff dreams are made of and the prime mover of discovery and creation in science, humanities, arts, and ourselves. ${ }^{4}$

In lyric poetry the poet works to make sure that the spirit of language-assound responds to the spirit of language-as-meaning, that language-as-sound incarnates language-as-meaning; that the spirit of language-as-meaning responds to the spirit of language-as-sound, that language-as-meaning inspirits language-as-sound. The resulting unity, experience, significant form, the poem, in other words, has no ornament, no other words. If the poet creates significant form, ${ }^{5}$ poems with rhyme, meter, stanzas are just as much poems as poems without them. Having followed Whitman so long, it's easy for us to forget that now, but a couple of hours with Bryant, Longfellow, and Whittier reminds us again how startling it was when Whitman proclaimed that poems without rhyme, meter, and stanzas are just as much poems as those with these things. ${ }^{6}$ And given the spirit of America, given its vastness and multitudes and powers, Whitman needed to explore the language itself to discover those things in it which resonate with America. "The United States themselves are essentially the greatest poem."7 Yes, but what will the poetry be like? If blank verse didn't resonate with the prairies (and Bryant had tried just that), what would? Whitman was determined to find out, and in his Preface of 1855 he had declared nothing less than the Manifest Destiny of poetry itself.

It didn't matter where he turned: to compost, trains, cradles and mockingbirds - the United States were everywhere. And so were the natural resources of language - in the sounds of words, the syntactic flows, the clinging 
of images, the uncharted idea of the poetic line itself, freed from counting fingers to exploring the spaces between them. It makes little difference where the poet turns, for, in Whitman's words, "the ground is always ready ploughed and manured. ... others may not know it but he shall. He shall go directly to the creation."8 The direct approach. Like moving West. And like moving West, the straightest distance between two points wasn't always a short line.

Sometime between 1855 and 1863, Whitman jotted down in a notebook the rough coordinates of what would later become one of the most moving lyrics in the English language:

First I wish you to realize well that our boasted knowledge, precious and manifold as it is, sinks into niches and corners, before the infinite knowledge of the unknown. Of the real world of materials, what, after all, are these specks we call knowledge?-Of the spiritual world I announce to you this - much gibberish will always be offered and for a season obeyed-all lands, all times - the soul will yet feel-but to make a statement eludes us-By curious indirections only can there be any statement of the spiritual world -and they will all be foolish-Have you noticed the [worm $]^{9}$ on a twig reaching out in the immense vacancy time and again, trying point after point? Not more helplessly does the tongue or the pen of man, essay out in the spiritual spheres, to state them. In the nature of things nothing less than the special world itself can know itself -10

They are rough because Whitman here is still groping toward the clear expression of statements that can't be made, toward the expression he would come to call "A Noiseless Patient Spider." At the beginning of the passage, in the process of acknowledging the value of propositional knowledge, of knowledge that, "precious and manifold," can be stated in "the real world of materials," Whitman emphasizes how insignificant such knowledge is in the face of felt knowledge, in the face of experiential knowing. What can be stated sinks away into "niches and corners." What can be stated is merely "specks" and "gibberish." In contrast, the "knowledge of the unknown," of the "spiritual world," deflects statement, "eludes us" even though "the soul will yet feel" that world. All direct statements of that world will be foolish, except by "curious indirections." And midway through the passage, Whitman turns to the indirections of analogy. The tentative nature of stating the spiritual world continues even here. The analogy comes in the form of a question, and the first part of the analogy is in first draft still to be discovered, an emptiness that "[worm]" later, most tentatively, fills in. The worm, that lowest creature of the ground, has reached a twig, an end of the line. And in its effort to continue, it reaches out in "immense vacancy" of physical space "time and again, trying point after point." Man's condition is like this in that the tongue or pen of man "essay out" in spiritual space and are just as helpless in making contact (the sense of attempt and trial bound up of course in the root meaning of "essay"). And the enormity of space that helps dwarf the 
already diminished worm is echoed by "spiritual spheres," a phrase which tends to locate man's attempt to connect in the middle of spiritual emptiness. Finally, the passage ends as it begins - with a statement that what lies beyond us in that "special world" is unknowable in this one.

An act of knowledge has failed, but the act of poetry has begun. The mere fact of the analogy itself gives substance to the unsubstantial. Perhaps it is the case that "nothing less than the spiritual world itself can know itself," but we can know what it's like to attempt to know it. Experiential versus propositional knowledge. And what that attempt is like lies at the center of this analogy. And other analogies have started to form, implicit analogies, where something in the physical nature of the linguistic event resonates with its what-is-said. The question that begins the analogy is itself an act of indirection. And the other sentences convey indirectness by inverting syntax, holding off the subject by means of an introductory phrase and expletive construction in the opening clause of the first sentence and by means of adverbial phrases in the third and fourth. The phrases "Time and again, trying point after point" perform by repetition-semantic repetition in the first phrase, word repetition in the second, phonological repetition throughout-the meaning of repeated action. The closed nature of the special world suggested by "spheres" is performed by repeating "itself," a reflexive pronoun whose linguistic nature (reflected in the name of the pronoun itself) bends back to close a reference in on itself. And finally, the passage as a whole closes back on itself as the last sentence reaffirms what the first sentence claims - that ordinary knowledge of the spiritual world is impossible. But on the whole in this passage, analogical thought is more stated than performed. Here we have brain but not enough blood.

The many directions Whitman went before finding the blood show up in a Civil War notebook (1862-1864; see Figure 1): ${ }^{11}$

The Soul, reaching throwing out for love. ${ }^{12}$

from some

As the spider, bh $\mathrm{a}$ little promon

tory, throwing out filament

out of

after filament, tirelessly ftbtn

itself

hitnself, that one at least

may catch, and form a

link, a bridge, a connection

as the the

saying hardly a

word,

O I saw one passing alone, athd sileht

-yet full of love I detected him by certain signs 
O eyes ever wishfully turning!

Wwishftully! $\mathrm{O}$ silent eyes

O those eydes thuthing [illeg.] it the street

For

Then I thought of you oer the world

$O$ the latent oceans, the fathomless

stweet oceans of love!

O

The waiting oceans of love! the

and of you

yearning and fervid! $\emptyset$ sweet souls

perhaps for

of the future, delicious and long:

But Dead,

Dyithy unknown on this earth-ungiven,

dark here, [illeg.]

unspoken, never born:

You

Those fathomless latent souls of love-

you

thbse`pent and unknown oceans

of love!

There are many problems in dealing with this early draft. First, the original has disappeared from the Library of Congress. ${ }^{13}$ Second, the extant photostats of the original lack the kind of detail necessary to resolve certain questions of punctuation and in some cases even of wording and lineation. Third, the only transcriptions of the original we do have and might depend on are occasionally but clearly at odds with the photostats and with each other. ${ }^{14}$ And finally, the draft appears divided into parts that don't easily fit together: the top line - "The Soul, reaching throwing out for love."-whose own set of problems I'll address later; the section starting with "As the spider" and ending with the line drawn after "as the the"; the section starting with "O I saw one" and ending with the line drawn after "O silent eyes"; and the section starting with "For Then I thought of you" and ending with "of love!"

The part beginning with "As the spider" continues many of the ideas of the earlier notebook. The creature is still lowly, the phrase "little promontory" indicates a surrounding emptiness, and the reaching is tireless. But the differences are crucial-the spider throws something of itself from out of itself; what is used to reach out is not the external, physical self but rather a manifestation of the inner, and the act is not as much one of trying to get from one location to the next as it is of linking, bridging, connecting. And instead of continuing with the second half of the analogy, Whitman begins again: "as the the" begins another example of reaching? begins to alter the 
first? begins completely anew? Whatever, this linguistic filament, an analogy in search of completion, a definite article in search of a noun, itself reaches out into silence, becomes silence, performs through silence the helplessness of stating the spiritual spheres.

The third part of the draft also turns to the individual apart, silent, seeking unspoken connections. This part seems to shift subjects but not theme, turning from the spider to a "him" in the streets, "passing alone, saying hardly a word," "O eyes ever wishfully turning!," "O silent eyes." Again the connection is unspoken but seen, and love is the filament. Whether it is the passing "one" who is full of love or the speaker himself who, full of love, silently watches for and would connect with other such watchers, the homoerotic undercurrents that would later surface in the "Calamus" poems here end in silence. The momentum built up in the second part of the draft has been lost, and the end of the third part is full of certain signs of again having run aground-repeated phrases and multiple deletions and finally a drawn line.

The fourth and last part of the draft turns still another way, the thirdperson pronouns giving way to "you," bridges giving way to the what-isbridged, to the space between them, to emptiness itself with its "latent," "waiting" "yearning," "future," "never born," "pent" potentiality. The world's oceans are transformed to "fathomless oceans of love," to "sweet souls" eager to enter the world, to be made real, to be spoken, to be born. This final part of the draft is haunting, losing itself in a special world, formless as water, "Dead, unknown" to this one, "ungiven, dark here, unspoken, never born." The immense, lost "latent" oceans of the world become "You fathomless latent souls of love." Spider and speaker disappear into the nothingness they would bridge. Whitman's revisions - "But Dead" for "Dying" and "You" for "Those"-make the dying final and the dead unborn familiar. And the surrounding entries in this particular notebook, filled with particulars of Civil War hospitals, suggest why his mind might have taken this turn toward the immense What-Might-Have-Been.

Though the page ends with the fourth part, it's not at all clear the draft's first line-"The Soul, reaching throwing out for love." - wasn't written last, or added in process as a first line, or used as a title, ${ }^{15}$ or written first, or something else. The photostats show the line in darker, thicker script, wedged in the little space between the "As the spider" line and the top of the sheet and cramped at the right-hand margin. It doesn't begin at the same left-hand margin as the first poetic line of the draft but it does have the same left-hand margin as do the poetic lines toward the end of the draft. Whatever it is, it stands alone, set off even further by its fragmentary syntax and by its reference to "The Soul," capitalized and singular, quite unlike the "sweet souls," "latent souls" toward the end of the draft. The line might easily have been an afterthought, last and first, and in fact it is a connection after all. Whatever the order of the line, it extends the analogy begun in the earlier notebook. 
Worm has become spider, the tongue or pen of man has become The Soul, and the unreachable spiritual sphere has become love. Whether title or part of the body of the poem, the line completes what "As the spider" begins, what the "as the the" reaches for.

In each part of the draft, whether working directly from the ideas of the notebook or from new ones, Whitman turns to analogy to reach what can't be directly expressed. And in each part, the physical activities of language join analogically with what is said. Beauty is forming-blood and brain. But which blood, which brain?

In October 1868 what might be considered the first "final" version of "A Noiseless Patient Spider" appeared in The Broadway. A London Magazine. (see Figure 2). ${ }^{16}$ It was published as the third section of "Whispers of Heavenly Death," "a poem" of five sections, each numbered, and each later appearing independently as a poem in the "Whispers of Heavenly Death" collection of Whitman's Passage To India ("Whispers of Heavenly Death," "Darest Thou Now, O Soul," "A Noiseless, Patient Spider," "The Last Invocation," and "Pensive and Faltering"). The editor of The Broadway treated the five sections as a single poem, proudly pointing out in a footnote that "This Poem has been written expressly for this Magazine." Reading the sections as one poem or five itself poses interesting questions of lyric structure, and exploring the differences of those readings is worthy of its own study. What Whitman intended in 1868 remains an open question, ${ }^{17}$ but by 1870 (the year Passage To India was printed) Whitman wanted the sections read as separate poems. And one aspect of The Broadway material strongly suggests that even in 1868 Whitman considered the sections separate poems. A common convention in printing poetry during the nineteenth century was to print the first word of a poem (or the second word when the first consisted of a single letter) in "lower-case capitals." Passage To India follows this convention and so does The Broadway for every poem it published-even those with numbered sections-except "Whispers of Heavenly Death." There each of the five sections follows the convention, each visually whispering its independence as a poem. ${ }^{18}$

3.

A NOISELESS, patient spider,

I mark'd, where, on a little promontory, it stood, isolated ;

Mark'd how, to explore the vacant, vast surrounding,

It launch'd forth filament, filament, filament, out of itself ;

Ever unreeling them-ever tirelessly speeding them.

And you, O my Soul, where you stand,

Surrounded, surrounded, in measureless oceans of space,

Ceaselessly musing, venturing, throwing, - seeking the spheres, to connect them;

Till the bridge you will need, be form'd-till the ductile anchor hold ;

Till the gossamer thread you fling, catch somewhere, O my Soul. 


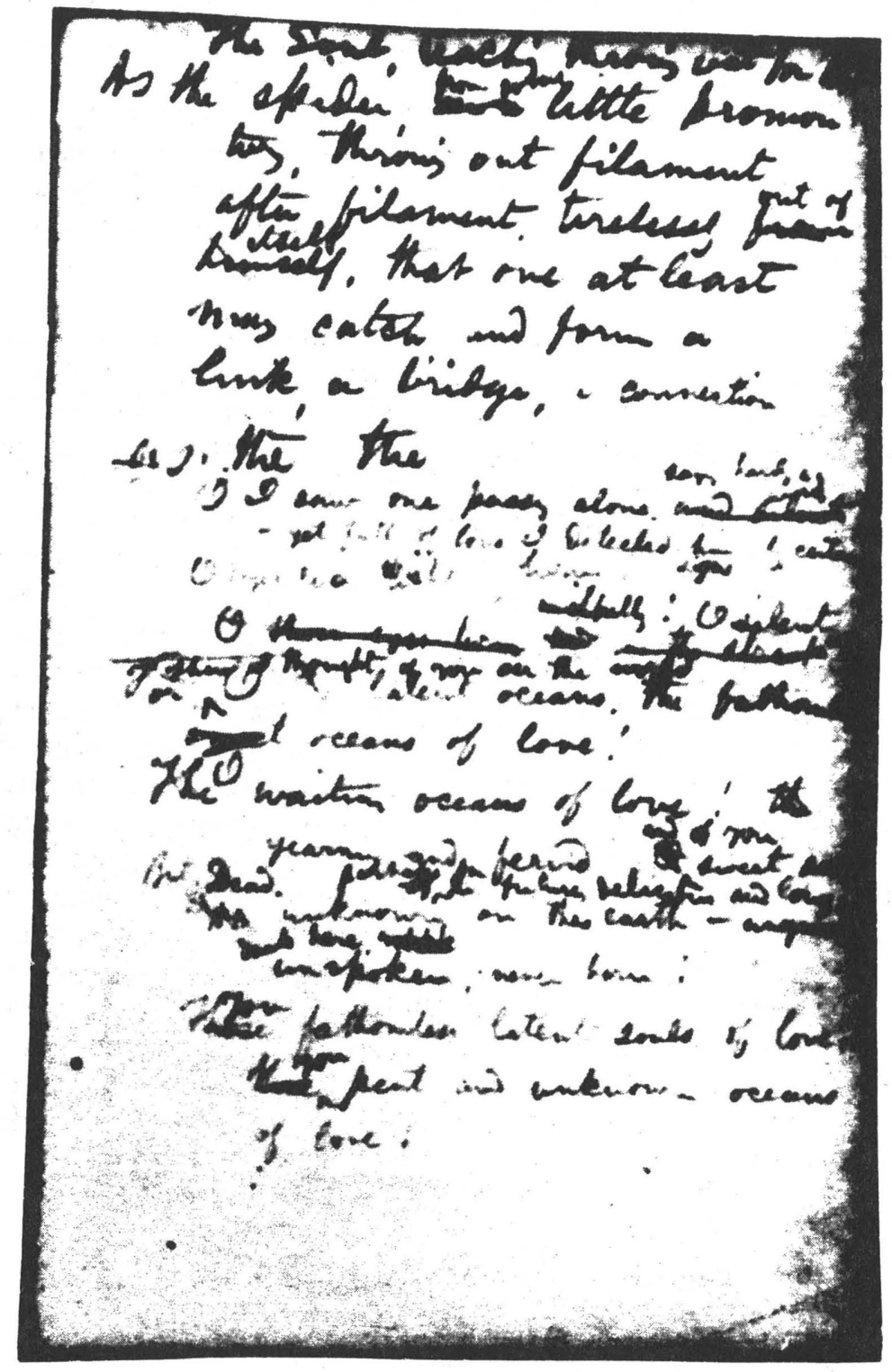

Figure 1. Photostat of Whitman's manuscript notes for "A Noiseless Patient Spider." Courtesy Library of Congress. 

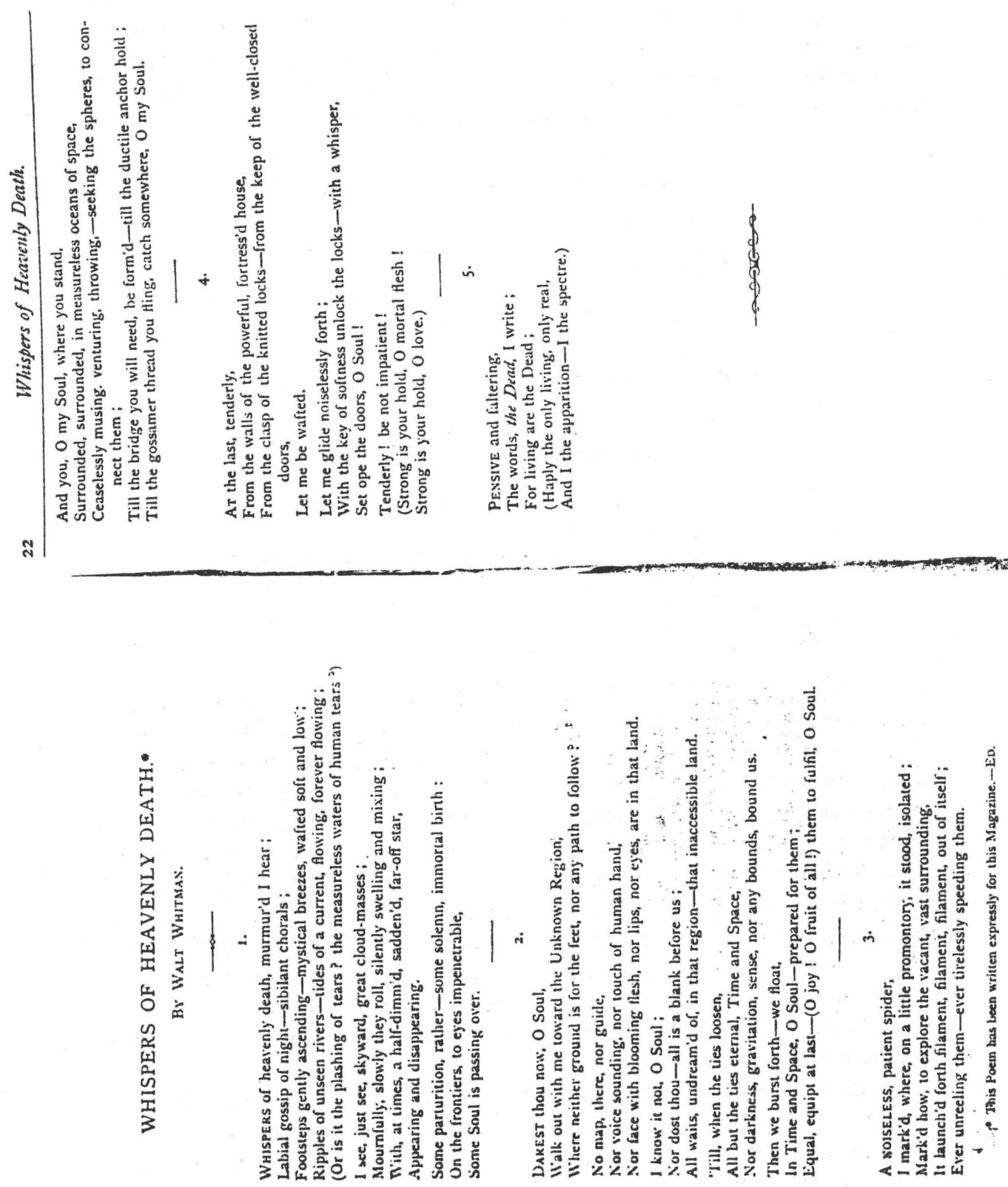

Figure 2. Whitman's "Whispers of Heavenly Death" as it appeared in The Broadway. 
The difference between The Broadway version and the version appearing in Passage To India (1871) is seemingly small. The 1871 version numbers the two stanzas and drops the comma after "NOISELESS" in line 1. Other than those differences and the indenting of several lines, necessitated by the format of Passage To India, ${ }^{19}$ the versions are identical.

\section{A NOISELESS, PATIENT SPIDER.}

1 A NOISELESS patient spider,

I mark'd, where, on a little promontory, it stood, isolated ;

Mark'd how, to explore the vacant, vast surrounding,

It launch'd forth filament, filament, filament, out of itself ;

Ever unreeling them-ever tirelessly speeding them.

2 And you, O my Soul, where you stand,

Surrounded, surrounded, in measureless oceans of space,

Ceaselessly musing, venturing, throwing, -seeking the spheres, to connect them;

Till the bridge you will need, be form'd-till the ductile anchor hold;

Till the gossamer thread you fling, catch somewhere, O my Soul.

Here the act of reaching, the act of exploring so central in the earlier attempts, at last catches and holds. The analogy of the original prose notes provides the stanzaic structure, and the different directions of the 1862-1864 draft provide powerful undercurrents of image and association. Much of the earlier material has been transformed or sublimated. ${ }^{20}$ The silence resulting from trying to state the spiritual spheres (in the prose notes) becomes the silence of determination and self-reliance. The spider who once threw filaments (1862-1864) now launches them out of itself, and the love explicitly reached for (1862-1864) becomes indistinguishable from the reaching itself. The spider's speechlessness (1862-1864) becomes the silence of patience. The addressed "you" - the "O waiting oceans of love" and the "fathomless latent souls of love" (1862-1864)-becomes "my Soul," alone in the measureless oceans of space.

And in creating the significant form we call "poem," Whitman also turned to something new, to a relatively unexplored natural resource of the mind. The line is no longer the conclusion of perceptual events but rather is a perceptual event itself. Here, as in his other poems, the poetic line, instead of being determined by phonological events (syllables, stresses, feet), itself determines events: the simple fact of line determines events. The frontiers that discovery opened form the landscape of poetry in English since Whitman. ${ }^{21}$ Poetry loosed from meter and rhyme shifts our attention from phonological 
to syntactic activities. ${ }^{22}$ In the first stanza, as we are carried along the uncertainties of rhythmic form, we are more sensitive to the reeling out of syntax, to how it catches on the end of lines, each line ending at the end of a major phrase or a clause. The repetition of syntactic structures and phrases and words, especially the present participles, and the constant interruption of caesura and syntactic inversion (the format of Passage To India heightening even more the sense of interruption by forcing visual-line breaks) ${ }^{23}$ help convey the sense of effort, the uncertainty of the reaching, the breaking off of unsuccessful attempts to begin again, and the continual cutting apart of what would be whole.

In addition to a situation distanced as memory and the object of attention distanced as third person, the noun phrase that makes up the first line of the poem, and that we assume will be the subject of the sentence making up the first stanza, alerts us to the uncertain, discontinuous nature of things the moment we are forced to recast the sentence, the moment we realize that " $\mathrm{A}$ NOISELESS patient spider" is not the subject of the sentence but an appositive, standing isolated from the clause it depends on, forcing "it" in line 2 into a disorienting back-connection. The comma after "mark'd" in line 2 isolates the noun clause that serves as the direct object of the verb and forces us to reconsider whether line 1 really is an appositive of the main clause after all or is the main clause's direct object. Further, "on a little promontory," by inverting the usual order of the syntax, isolates "isolated," isolated even further by its status as a nonrestrictive modifier ${ }^{24}$ and by its being set off as a visual-line (even the nineteenth-century convention of preceding a semicolon with a space - as was the case for colons, exclamation marks, and questions marks adds to the sense of apartness for the twentieth-century reader). Then out of these difficulties, things more easily flow. Line 3 parallels the inverted syntax of line 2 and therefore unreels more easily. The "how" clause after the "mark'd" in line 3 is not set off from the verb as the "where" clause is in line 2. Sounds, ${ }^{25}$ words, and the nature of the images themselves contribute to the unreeling: "vacant, vast"; "forth filament, filament, filament"; "Ever unreeling them-ever tirelessly speeding them." However insignificant and alone and unmoving ("stood") the spider is, it still explores the emptiness around it by launching something from "out of itself."

The second stanza continues the exploring in the literal sense of "exploring," a crying out -the self's reach its noiseless cry-to reconnect the scattered spheres of the once Ptolemaic universe, to make things whole again, however gossamery the link, however ductile the hold. The opening two lines of the stanza continue much of the first stanza. The Soul too is marked in its isolation, as a sentence fragment, dependent on the previous sentence for its unstated subject and verb; ${ }^{26}$ as "you," a second person drawn from out of the first, set off as a noun of direct address, set apart from the "I" by being addressed, set apart from the understood subject and the verb "I mark'd" or "I mark" that give it meaning as an object. The Soul too does not move ("stand") 
but throws threads from out of itself. But unlike the first stanza ("I mark'd, where . . . it stood ${ }^{\text {") }}$, the situation is immediate, not remembered, either in the eternal present implied by "[I mark'd] . . . where you stand" or in the immediate now implied by "[I mark] . . . where you stand." The idea of spider washes away in the nautical images transformed from the 1862-1864 draft as the poem moves from the entity that creates connections from out of itself to the relentless flinging of language itself. Finally Whitman had his beautyblood and brain.

And in the 1881 edition of Leaves of Grass, ${ }^{27}$ Whitman reached out again:28

\title{
A NOISELESS PATIENT SPIDER.
}

\begin{abstract}
A NOISELESS patient spider, I mark'd where on a little promontory it stood isolated, Mark'd how to explore the vacant vast surrounding, It launch'd forth filament, filament, filament, out of itself, Ever unreeling them, ever tirelessly speeding them.
\end{abstract}

And you $\mathrm{O}$ my soul where you stand, Surrounded, detached, in measureless oceans of space, Ceaselessly musing, venturing, throwing, seeking the spheres to connect them,

Till the bridge you will need be form'd, till the ductile anchor hold,

Till the gossamer thread you fling catch somewhere, O my soul.

Here the sense of a never-ending exploration becomes primary, washing away many of the previous caesuras. The dramatic shift from the earlier versions seems surprising at first, but Whitman early on hints such a move is possible. The title announcing the poem in Passage To India-"A NOISELESS, PATIENT SPIDER."-preserves the comma after "NOISELESS" in the first line of The Broadway version. But the first line of the poem itself in Passage To India omits the comma. Someone having been careless with the proofs or Whitman simply being undecided about a detail: either seems like a plausible explanation until we turn to the table of "Contents," undoubtedly arranged after the poems themselves had been set. There the title also omits the comma- "A Noiseless Patient Spider." By 1881, not only was this particular comma gone for good, so was over a third of the rest of the punctuation. In Leaves of Grass (1881), eleven commas in the Passage To India version have been dropped and all the dashes and semicolons changed to commas. These changes are in keeping with Whitman's overall movement toward simplification in the 1881 edition, but the effects on this particular poem are breath-taking, quite literally. The phrasal/clausal breaks are still there but not the overt invitations to take breaths at those junctures, and the 
result shifts emphasis away from the parts toward the whole, from the individual phrase to the line (dropping the stanza numbers has the same effect on a larger scale). The punctuation that is left behind-marking line ends and syntactic items in a series-marks for the most part the boundary between any punctuation in poetry and none at all, the latter often the choice of twentieth-century poets, especially at ends of lines and other prosodic structures.

The commas Whitman passed up omitting are few but telling. The comma after the third "filament" in line 4 isn't necessary to negotiate the series nor for setting off the following prepositional phrase, but it is necessary for reinforcing the independence of that filament, and by implication, of each filament, each attempt, each exploration. The comma after "detached," the word replacing "surrounded" in line 7, helps secure the sense of apartness implied but unstated in the second stanza of the earlier versions. That "detached" isn't "detach'd," as Whitman's practice with apostrophes would lead us to expect, is also telling (note "launch'd" in particular). Given the visual separation of the $d$ from the rest of the word, it would seem such a practice would contribute to the sense of separation. But for Whitman, using the apostrophe in place of the silent $e$ in the past tense and past participle of certain verbs drew things together, constituted a "closening of words." 29 For us, the word hits hard precisely because it doesn't follow Whitman's usual practice; for Whitman, such a spelling must have given the word an even stronger sense of its meaning, of the brokenness that might be whole. And finally, the comma in line 10, especially after line 6 avoids setting off the same noun of direct address, leaves the "soul" (reduced from the "Soul" of earlier versions $)^{30}$ on its own little promontory. Overall, the changes in Whitman's final version leave the soul even more alone, a fact that makes more intense the sense of trying to connect as we move through the poem, without traditional platforms of scheme, through the uncertain lengths of line, right up to the gossamer connection that ends the poem, the ductile-rhyme of "hold" and "soul."

The three final versions of "A NOISELESS PATIENT SPIDER" are as similar and as different as the leaves of grass Whitman loved. And each version, in joining the physical and semantic acts of language, in marrying brain and blood in different ways, achieves its own beauty. Each is in Whitman's words, again from the Preface of 1855, the "cleanest expression," for in finding "no sphere worthy of itself," each "makes one." 31

\section{The University of Iowa}

\section{NOTES}

1 Walt Whitman, "Preface 1855," Leaves of Grass, Comprehensive Reader's Edition, ed. Harold W. Blodgett and Sculley Bradley (New York: New York University Press, 1965), 716. 
2 "Unerringly" is a wonderfully appropriate word here, coming from the Latin word errare, to wander. Whitman is calling for directed form and movement, not for a wandering about. The question was never should there be form but rather what directs its growth, and throughout his poetry the emphasis remains on process, not the produced.

3 See, as a prime example, "The Analogous Form" section in Gay Wilson Allen's The New Walt Whitman Handbook (New York: New York University Press, 1975), 207-211.

4 See "The Problem Solver," Chapter 7 of Morton Hunt's The Universe Within (New York: Simon and Schuster, 1982).

5 Or as Susanne Langer says in Philosophy in a New Key, Third Edition (Cambridge, Massachusetts: Harvard University Press, 1978), 261-262: “'Artistic truth' does not belong to statements in the poem or their obvious figurative meanings, but to its figures and meanings as they are used, its statements as they are made, its framework of word-sound and sequence, rhythm and recurrence and rhyme, color and image and the speed of their passage-in short, to the poem as 'significant form.' The material of poetry is discursive, but the product - the artistic phenomenon-is not; its significance is purely implicit in the poem as a totality, as a form compounded of sound and suggestion, statement and reticence, and no translation can reincarnate that." [Emphases are Langer's.]

6 Eleven years before in "The Poet" Emerson had also rejected the idea that poetry is a "music-box of delicate tunes and rhythms," insisting that "it is not metres, but a meter-making argument, that makes a poem." Emerson's position differs from Whitman's in important ways (for example in the priority of thought over form "in the order of genesis"), but the most important difference was that Whitman showed how it could be done. For a summary of Whitman's own deeply ambivalent views of his place vis-à-vis Emerson's in the poetic tradition, see Kenneth M. Price's "Whitman on Emerson: New Light on the 1856 Open Letter," American Literature 56 (March 1984), 83-87.

7 Walt Whitman, "Preface 1855," LG, 709.

8 Walt Whitman, "Preface 1855," LG, 715.

9 Whitman's brackets.

10 Walt Whitman, Notebooks and Unpublished Prose Manuscripts, ed. Edward F. Grier (New York: New York University Press, 1984), 6:2051.

11 NUPM, illustration following 2:700.

12 My own attempt at a transcription, from the illustration following 2:700 in NUPM. My version differs in significant ways from Edward Grier's transcription (NUPM, 2:522-523).

13 See NUPM, 2:478.

14 The transcription in NUPM, 2:522-523 is based on a photostat of the original manuscript. See William E. Barton, Abraham Lincoln and Walt Whitman (Indianapolis: Bobbs-Merrill, 1928), 51-52, and Emory Holloway, ed., The Uncollected Poetry and Prose of Walt Whitman (New York: Doubleday, 1921), 2:93, for transcriptions taken from the manuscript itelf, clearly at odds with the photostat and with each other and therefore not overly reliable.

15 The period at the end of the line conveniently follows the convention of the time for titles.

16 Walt Whitman, "Whispers of Heavenly Death," The Broadway. A London Magazine, New Series, Vol. I, September 1868 to February 1869 (London: George Routledge and Sons), 21-22. My thanks to Cathy Henderson, Research Librarian of the Harry Ransom Humanities Research Center at The University of Texas at Austin, for providing the Whitman material from The Broadway printed here and for other background materials. 
17 Whitman himself generally referred to The Broadway material by its title or as the "piece," though in a letter to Abby Price (April 10, 1868) he writes of publishing a prose "piece" in The Galaxy and "a poem soon" in The Broadway. See Walt Whitman, The Correspondence, ed. Edwin Haviland Miller (New York: New York University Press, 1961), 3:26. See also 3:14, 24, $44,46,47$.

18 There is a page break after line 5. My assumption that a stanza break also comes after line 5 is based less on The Broadway than on subsequent versions.

19 Walt Whitman, “A Noiseless, Patient SPIDER," Passage To India (New York: Smith and McDougal, 1871), 69.

20 For other suggestions of this process of sublimation see Gay Wilson Allen and Charles T. Davis, eds., Walt Whitman's Poems (New York: Grove Press, 1959), 197-199, and LG, 450.

21 For a sketch of this landscape, see my "Rhythmic Form in Twentieth Century American Lyric," Ars Lyrica, 5 (1988), 55-70.

22 For other approaches to Whitman's exploration of the language, see C. Carroll Hollis's Language and Style in Leaves of Grass (Baton Rouge: Louisiana State University Press, 1983), and James Perrin Warren's "The 'Real Grammar,': Deverbal Style in 'Song of Myself,' "American Literature 56 (March 1984), 1-16.

23 The affective consequences of "visual-lines" (lines forced when poetic lines run out of paper on the right-hand side) being mistaken, transformed, and exploited are an important aspect of the evolution of rhythmic form in twentieth-century poetry in English. Reading The Broadway and Passage To India versions side by side provides a good example of the effect.

24 For a close hand look at the possibilities of nonrestrictive modifiers and for the liberating effect of considering sentences dynamically rather than as static structure, more akin to rivers than to buildings, see Francis Christensen's work on nonrestrictive modifiers, what he calls "free modifiers," especially the opening essays in his Notes Toward a New Rhetoric (New York: Harper and Row, Publishers, 1967).

25 By focusing on syntactic matters, I don't mean to suggest phonology doesn't play an important role in this poem. Consider, for example, the roles played by stops (phonemes where the flow of sound is stopped: $p, b, t, d, k, g$ ) and by continuants (here referring to consonants where the flow of sound may be prolonged as long as breath lasts). Lines 1 and 2, concentrating on marking, placing, standing, isolating, have the highest percentage of stops (number of stops divided by number of all consonants) in the first stanza: $40 \%$ and $45 \%$. Line 9 , concentrating on a formed bridge, on an anchor that holds, on the need to hold things in place in the midst of flux, has the highest percentage of stops: $46 \%$ (and consequently the lowest of continuants) in the poem. Line 3, that really begins the unreeling of syntax and images of movement, also begins a dramatic increase in the percentage of continuants (number of continuants divided by number of all consonants): from $60 \%$ and $55 \%$ in lines 1 and 2 to $61 \%$ in line 3 to $76 \%$ in line 4 to $82 \%$ in line 5 , a flood of sounds that, with the exception of line 9, mentioned above, continues for the rest of the poem: $80 \%, 81 \%, 78 \%, 54 \%$ (line 9), 76\%. These phonological events aren't symbols for the thematic or syntactic events in the poem - they are events in and of themselves, often experienced beyond awareness, more blood than brain and just as real.

26 See Charles R. Kline and W. Dean Memering's "Formal Fragments: The English Minor Sentence," Research in the Teaching of English, 11 (Fall 1977), 97-110, for an introduction to the felicitous use of fragments, what Kline and Memering call "minor sentences," even in prose. Also see Emily Dickinson's "The Bustle in a House" (\#1078) for what may be a fragment used as the second of two stanzas. There the verb and complement are the invisible presences.

27 Walt Whitman, "A NOISELESS PATIENT SPIDER," Leaves of Grass (Boston: James R. Osgood and Co., 1881-82), 343. 
28 The variorum - Walt Whitman, Leaves of Grass, A Textual Variorum of the Printed Poems, ed. Sculley Bradley, et al. (New York: New York University Press, 1980), 3:585-ignores the fact that in the 1881 edition the title of the poem is in capitals and that "NOISELESS" in the first line is in "lower-case capitals."

29 Horace Traubel, With Walt Whitman in Camden (1905; rpt. New York: Rowman and Littlefield, 1961), 1:248.

30 A change made throughout the 1881 edition of Leaves of Grass.

31 Walt Whitman, "Preface 1855," LG, 717. 